\title{
Common Variable Immunodeficiency: Endoscopic and Pathological Findings
}

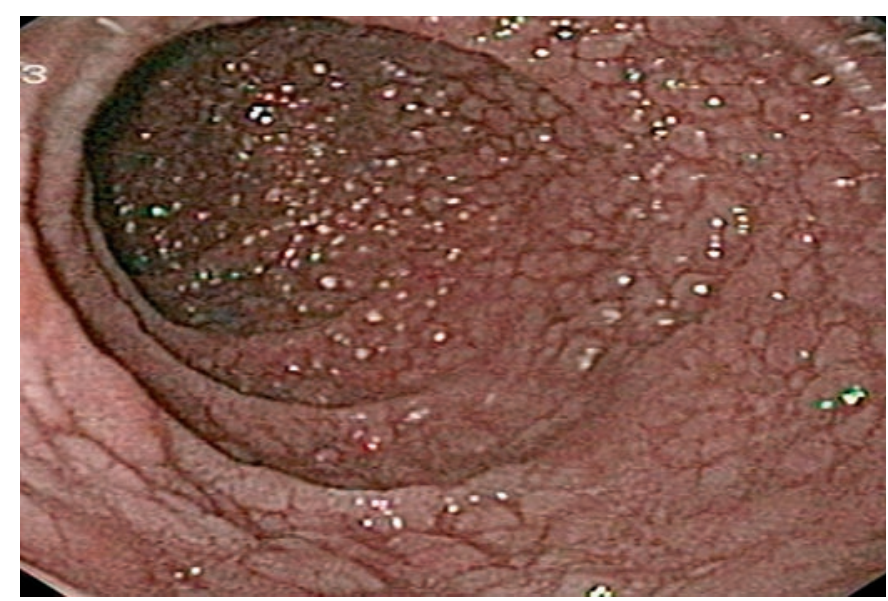

Figure 1 A 24-year-old man presented with chronic diarrhea. Mild splenomegaly was observed during the physical examination. Upper gastrointestinal endoscopy revealed numerous polypoid lesions in the duodenum.

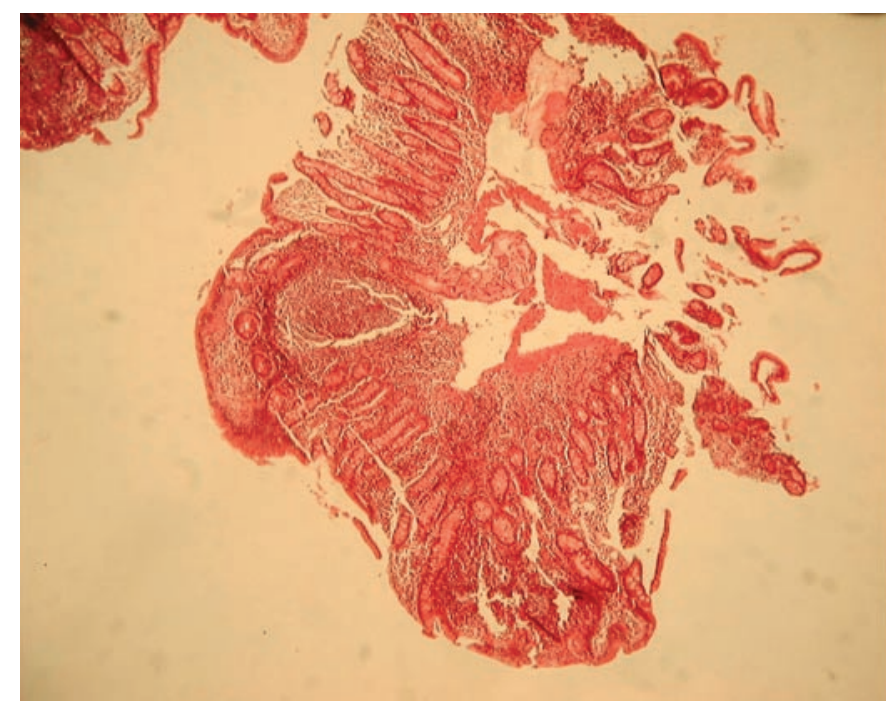

Figure 2 Mucosal biopsies were taken from the lesions. Histologically, there was a severe malabsorption pattern consisting of villous atrophy, crypt hyperplasia, lamina propria mononuclear cell infiltration, and absence of plasma cells, together with marked lymphoid nodular hyperplasia. Serum protein electrophoresis revealed hypogammaglobulinemia. Quantitative measurement of immunoglobulins revealed low serum levels of $\mathrm{lgG}, \mathrm{IgA}$, and $\mathrm{lgM}$. A diagnosis of common variable immunodeficiency was made.

\section{F. Sadr, M. Mohamadnejad,}

R. Malekzadeh, M. Sotoudeh

Digestive Disease Research Center, Shariati Hospital, Tehran University of Medical Sciences, Tehran, Iran

\section{Corresponding Author}

\section{R. Malekzadeh, M.D.}

Digestive Disease Research Center Shariati Hospital

N. Kargar St.

Tehran 14114

Iran

Fax: $\quad$ +98-212253635

E-mail: malek@ams.ac.ir 